\title{
The Effects of The Second Largest Shareholders on Earnings Management in Korea's Mutual Savings Banks
}

\author{
Hyun-Jung Kang and Soon-Mi, Yu \\ ${ }^{1}$ Dept. of Accounting, Gyeongsang National University \\ 504, Jinju-daero. Jinju city 660-701, South Korea \\ 'hjkang8@gnu.ac.kr, ${ }^{2}$ smyu@gnu.ac.kr
}

\begin{abstract}
This study examines whether the second largest shareholders are related to the earnings management of Mutual Savings Banks in Korea from 2003 to 2012. A negative relationship is found between the second largest shareholders and the discretionary portion of the allowance provisions.In general, most of the Mutual Savings Banks in Korea have a single largest blockholder, so the possibility of earnings management for the largest shareholder's private interest is higher than other financial institutions. However, if the firms have multiple blockholders, the second largest shareholder can exercise their control over banks. Then the shareholders can eliminate or supervise the earnings management for the largest shareholder's private interest. In this regard, the paper verifies whether Mutual Savings Banks (MSB), with higher equity from the second largest shareholder can reduce the earnings of management by discretionary allowance for loan losses. We find that banks from the second largest shareholder with higher equity, has significant negative relations with the Discretionary portion of Allowance for Loan Losses (DALL). This result suggests that the greater the second largest shareholder's equity, the less likely the opportunistic earnings management. This paper extends the literature on financial institutions' earnings management to verify whether governance systems, especially ownership structure and earnings management, have significant relations.
\end{abstract}

Keywords: Mutual Savings Bank, Corporate Governance, Second Largest Shareholder, Earnings Management, Provision for Loan Losses

\section{Introduction}

Mutual Savings Banks have been developed for the working classes' financing purpose, and provides petty loans for working class people. Due to increasing needs of the working class finances, Mutual Savings Banks grew rapidly with higher interest rates and increased their loans with fewer regulations. During the Asian financial crisis (IMF crisis) of 1998, the needs of the working class' finances reached a high. The industry and the government focused on the rapid growth of the savings banks' external growth rather than asset soundness. Under these circumstances, Mutual Savings Banks slackened their regulations more than other financial institutions. In particular, the ownership restriction, which is strictly applied for most financial institutions, is not regulated for Mutual Savings Banks. In general, the nation-wide banks' shareholders cannot hold more than $10 \%$ of bank shares, and for local banks, that number is $15 \%$. Also, the shareholders who hold more than $4 \%$ of bank shares have to report their shares to supervisory authorities. This exemption enables a single blockholder of Mutual Savings Banks to hold large shares with no limit. The result being that the average largest blockholder ratio reached over 50\% in 2011. Using their concentrated ownership structure, some blockholders of Mutual Savings Banks held strong control over the firm and were more likely to manage the firm's earnings to protect their private interests such as illegal loans to related parties, 
or misuse of bank assets. That concentration of ownership, the manager's strong power over the firm, and a moral hazard of the manager were the important causes of the Mutual Savings Bank crisis in 2011.

According to a statement in July 2014 by the Financial Supervisory Service, the largescale restructuring of mutual savings banks has been carried out and allows large lenders to take over insolvent savings banks. The result of Mutual Savings Banks crisis ended up with more than 30 insolvent banks. Starting with the bankruptcy of Samhwa Savings Bank in January 2011, a total of 16 savings banks closed in 2011, including Busan Mutual Savings Bank (the biggest mutual savings bank at that time). In addition, the closure of 8 more banks in 2012 and 6 banks in2013. Since Mutual Savings Banks customers generally consist of various segments of working classes and small sized firms, the social impact of insolvent banks may exceed those of other financial institutions.

In this regard, the importance of governance structure, especially the ownership structure, of the Mutual Savings Banks has been increased. Generally, when the largest shareholder holds most of the firms equity, the earnings management for their private interest also increased. However, some research showed that if there were multiple blockholders and if a second largest shareholder had effective control over the banks, the possibility of earnings management by the largest blockholder could be reduced.

[1] (Pack, Cho, 2006) analyzed whether the largest stockholder's equity holdings actually cause a firm to manage its earnings and whether this depends on a firm's equity ownership structure. They found that the bigger the largest stockholder's equity holdings became, the more likely a manager opportunistically increases the earnings and earnings management is more prominent in manager-controlled companies than in ownercontrolled companies, the third, the bigger he second largest stockholder's monitoring role is, the more limited the largest stockholder's inventive is to engage in opportunistic behaviors .

In this regard, we predict that it is more difficult for the Mutual Savings Banks with the second largest shareholders and their highest holdings to manage their earnings. Thus, we investigate whether savings banks with the highest holdings have less opportunistic earnings management using Discretionary portion of Allowance for Loan Losses (DALLs).

Using a sample of 688 Mutual Savings Banks in Korea from 2003 to 2012, we examine whether the magnitude of Discretionary portion of Allowance for Loan Losses (DALLs) is related to the second largest shareholder's holdings. We find significantly negative associations between Discretionary portion of Allowance for Loan Losses (DALLs) and the second largest shareholders. These findings support the hypothesis that earnings management is negatively related to the second largest shareholders.

Thus far, most studies have focused on whether financial institutions use Discretionary portion of Allowance for Loan Losses (DALLs) for earnings management or capital adequacy purpose. And very little research examined the financial institutions' earnings management in terms of governance structure: especially, ownership structure. In this regard, this paper connects the Mutual Savings Bank's governance system, especially the ownership structure to their earnings management mechanism. This paper contributes to the literature by providing further evidence of the relationship between the ownership structure of Mutual Savings Banks and their earnings management by the Provision for Loan Losses.

\section{Literature Review}

\subsection{Governance Structure and Earnings Management}

Research on the relations between blockholders and earnings management shows two different hypothesis: One is the expropriation of minority shareholders' hypothesis. Under 
this hypothesis, ownership by large investors (blockholders) matches significant control rights and the possibility of earnings management for their private interest increasing. [2] (Shleifier, vishny 1997), [3-4] (La Porta et. al 1998, 2000) investigated the relationship between ownership concentration in corporate governance systems and legal protection. They found that large shareholders play an active role in corporate governance and have outright control of the firms and their management. As a result, there is a potential expropriation by large shareholders of other shareholders.

[5] Park (2003) investigated the relationship between corporate governance and earnings management and found there exists a significant positive relation between the largest shareholder's holding and discretionary accruals, which consists with the expropriation of minority shareholders' hypothesis. Also, there exists a significant negative relationship between the largest shareholder's holdings and the absolute value of discretionary accruals that supports the convergence of the interest hypothesis. [6](Park et. al. 2006) investigated the relationship between corporate governance and earnings management and found that corporate governance is positively associated with discretionary accruals. They found that as one large shareholder's equity is increasing, discretionary accruals would be increased and affected on book-tax earnings difference.

Recent empirical work shows the importance of multiple large shareholders' control contests. If there are control contests among multiple large shareholders, they could compete and oversee each other, so the possibility of expropriation by the largest shareholder could be reduced. [7]Ahn et. al., (2012) investigated the role of the multiple largest shareholders and the contestability among those shareholders and earnings management. They found that the contestability of the largest shareholders and firms' earnings management by accruals had negative (-) relations

\subsection{Earnings Management in Financial Institutions}

[8]Beatty examined how banks alter the transaction timing and magnitude and accruals to achieve capital adequacy, tax purpose and earnings goals. Their study shows that taking simultaneity into account is important for three of the five modeled choices, namely loan charge-offs, loan-loss provisions, and securities issue decision. [9] Moon examined the Korean bank's opportunistic accounting choice for Loan Loss Provisions (LLPs) from 1995 to 2001 and found that the banks were using Loan Loss Provisions (LLPs) to manage their earnings. She investigated whether banks with poor (or good) performance adjusted Loan Loss Provisions(LLPs) to manage earnings and found that banks smooth their earnings over time by Loan Loss Provisions(LLPs).

[10] Cornett examined whether corporate governance mechanisms affect earnings management at the largest publicly traded bank holding companies in the United State. They investigated the largest bank holding companies headquarters in the U.S and operating during the 1994 through 2002 period using DLLP (Discretionary Loan Loss Provisions) and RSGL (Realized Security Gains and Losses). They found the CEO paid for performance, board independence, and capital, which are positively related to earnings, and that earnings, board independence, and capital are negatively related to earnings management.

\section{Hypothesis}

Most financial institutions separate the ownership and management systematically by regulation. However, the Mutual Savings Banks blockholders can have most of the banks equities since they do not have strict ownership restriction. Espicially, the ownership is concentrated in one or a small number of large shareholders. The average shares of the largest shareholder's holdings in a Mutual Savings Bank is over 60\% during the 20032012 period. In general, the largest blockholder has ultimate ownership and strong control 
over the firm. This controlling power enabled them to affect the firm's decision-making process.

Empirical research shows the blockholder affected the manager's earnings management decision process to protect their private interests and may expropriate other investors and stakeholders of the firm. In these regards, we predict that if the ownership structure of the Mutual Savings Bank is diversified and the second largest shareholder has enough controlling power, the earnings management for blockholder's private interest can be eliminated. This suggests a negative relationship between the second largest shareholder ratio and earnings management and leads to this paper's null hypothesis:

$\mathrm{H}$ : The second largest shareholder ratio is not related to the discretionary shares of the allowance account.

\section{Research Methods}

\subsection{Model}

The effects of the second largest shareholders on earnings management is modeled as a function of the aforementioned hypothesis by using a regression analysis with the following constructs:
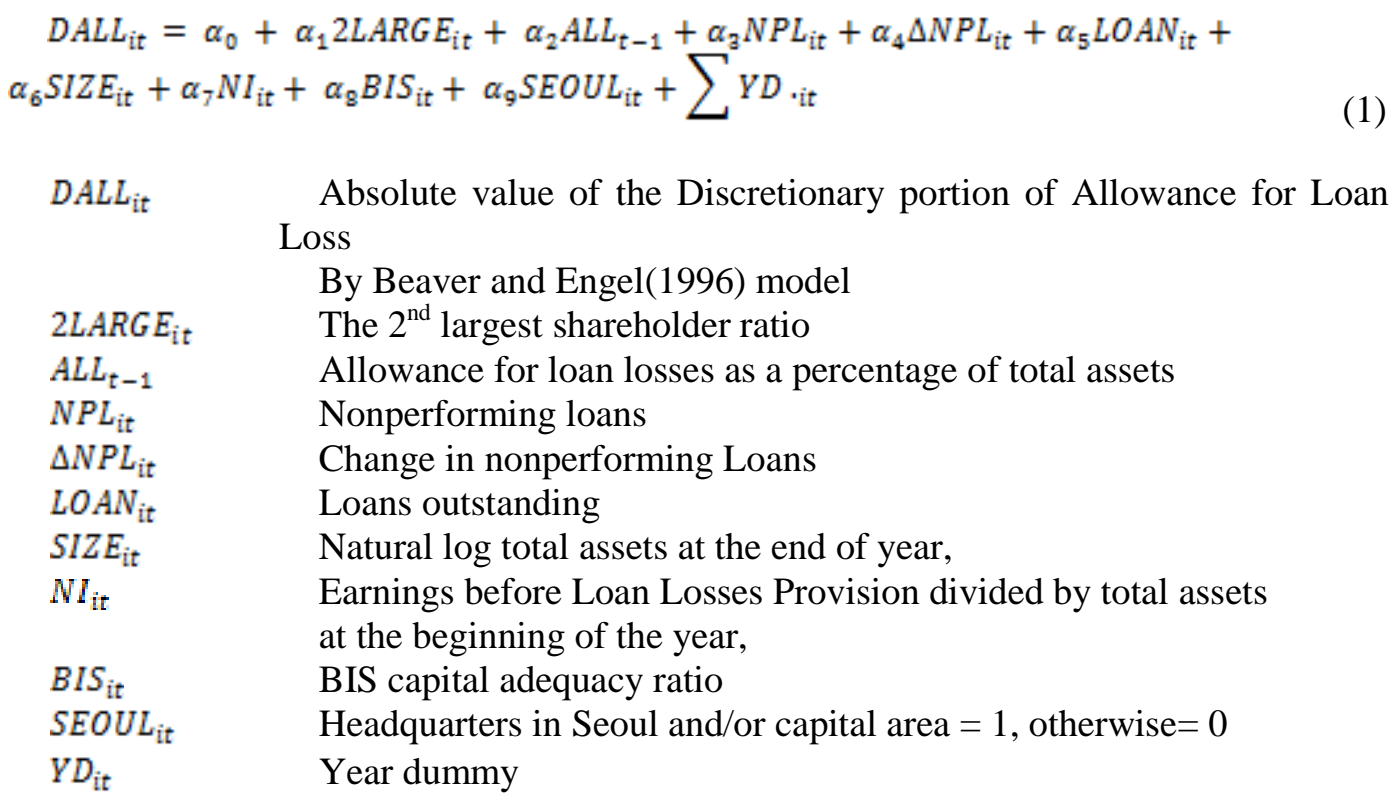

The coefficient for the Second Large Shareholder is of primary interest in this paper. The coefficient $\alpha_{1}$ is expected to be negative. We use ALL, NPL, $\triangle$ NPL, LOAN, SIZE, NI, BIS, SEOUL as control variables, To estimate the allowance for Discretionary portion of Allowance for Loan Losses (DALLs), we follow the [11] Beaver and Engel model.

$$
N a l l_{\text {it }}=\gamma_{0}+\gamma_{1} C O_{\text {it }}+\gamma_{2} L O A N_{\text {it }}+\gamma_{2} N P A_{\text {it }}+\gamma_{4} \Delta N P A_{\text {it }+1}+\mu_{\text {it }}
$$

\subsection{Sample Selection}

The sample includes all Mutual Savings Banks in Korea. The data set includes financial statements of all Mutual Savings Banks in the KIS-VALUE dataset for the period of 2003-2012. The largest and second largest shareholder data is from the bank's annual report and KIS-VALUE. We excluded the samples, which do not disclose shareholders' ratios and/or other financial information. 
Table 1. Sample

\begin{tabular}{|l|l|l|l|l|l|l|l|l|l|l|l|}
\hline & 2003 & 2004 & 2004 & 2006 & 2007 & 2008 & 2009 & 2010 & 2011 & 2012 & Total \\
\hline Sample & 76 & 66 & 75 & 76 & 78 & 92 & 81 & 79 & 82 & 75 & 780 \\
\hline Exclusion & 11 & 7 & 9 & 8 & 10 & 23 & 8 & 4 & 7 & 5 & 92 \\
\hline Final & 65 & 59 & 66 & 68 & 68 & 69 & 73 & 75 & 75 & 70 & 688 \\
\hline
\end{tabular}

\subsection{Results}

Table 2. Descriptive Statistics (n: 688)

\begin{tabular}{llllll}
\hline Variable & Mean & Min & Median & Max & \multicolumn{1}{c}{ Std.Dev } \\
\hline DALL & 0.0146 & 0.0000 & 0.0108 & 0.1000 & 0.01431 \\
2LARGE & 11.6955 & 0.0000 & 10.640 & 48.0000 & 11.6840 \\
ALL(t-1) & 0.0469 & 0.0000 & 0.0356 & 0.5700 & 0.0407 \\
NPL & 0.0998 & 0.0000 & 0.0794 & 0.4700 & 0.0646 \\
$\triangle$ NPL & 0.0096 & -0.2900 & 0.0079 & 0.2300 & 0.0547 \\
LOAN & 0.7902 & 0.0500 & 0.7929 & 2.1600 & 0.2300 \\
SIZE & 26.2725 & 23.8500 & 26.1953 & 29.3700 & 1.0461 \\
NI & 0.0270 & -0.1300 & 0.0237 & 0.2400 & 0.0297 \\
BIS & 13.1807 & -19.2100 & 10.77 & 108.1100 & 11.6863 \\
SEOUL & 0.5218 & 0.0000 & 1.0000 & 1.0000 & 0.4999 \\
\hline
\end{tabular}

Table 2. presents descriptive statistics for the sample banks for 2003 2012. The mean and median ratio of the absolute value of Discretionary portion of Allowance for Loan Losses (DALLs) is 0.0146 and 0.0108 respectively. The mean and max of the second largest shareholder's equity is 11.6955 and 48.00 respectively.

The change in non-performing loans has been used as a measure of default risks. The median of change in non-performing loans is 0.079 of total assets in our sample. The mean of the SEOUL is 0.5218 , indicating that $52.18 \%$ of our samples headquarter is located in Seoul and/or the Capital aria.

Table 3. Person Correlations

\begin{tabular}{|c|c|c|c|c|c|c|c|c|c|c|c|}
\hline & DALL & $\begin{array}{l}\text { 2LARG } \\
\text { E }\end{array}$ & ALL & NPL & $\Delta \mathrm{NPL}$ & LOAN & SIZE & NI & BIS & SE & \\
\hline $\begin{array}{l}\text { 2LARG } \\
\text { E }\end{array}$ & -.034 & 1 & & & & & & & & & \\
\hline ALL & .404 & .056 & 1 & & & & & & & & \\
\hline NPL & .525 & .046 & .472 & 1 & & & & & & & \\
\hline$\triangle \mathrm{NPL}$ & -.242 & -.045 & -.286 & -.280 & 1 & & & & & & \\
\hline LOAN & -.097 & .040 & -.085 & .037 & .286 & 1 & & & & & \\
\hline SIZE & .004 & .045 & .001 & .108 & .012 & .199 & 1 & & & & \\
\hline NI & -.038 & .006 & -.032 & -.070 & .173 & .421 & .146 & 1 & & & \\
\hline BIS & .008 & -.008 & -.014 & -.259 & -.002 & -.278 & -.380 & $\begin{array}{l}.05 \\
6\end{array}$ & 1 & & \\
\hline SEOUL & -.085 & .015 & -.061 & .051 & .057 & .230 & .512 & $\begin{array}{l}.21 \\
7 \\
\end{array}$ & -.022 & & 1 \\
\hline
\end{tabular}

Note: Bold numbers on the diagonal indicate significance at 1\%, 5\% level (two-tailed test)

Table 3 shows a correlation matrix for the main variables. DALL and 2Large are negatively correlated. Among control variables, $A L L_{t-1}, N P L$ are positively correlated with $D A L L$, whereas $\triangle N P L_{t+1}, L O A N$, and $S E O U L$ are negatively correlated. 


\section{Table 4. Regression Results for the Discretionary Provision for Loan Losses and the Second Largest Shareholder of MSB (n: 688)}

\begin{tabular}{llll}
\hline Variable & Sign & Coefficient & T-statistic \\
\hline Intercept & & $\mathbf{- 0 . 0 2 7}$ & $\mathbf{- 1 . 8 3 2}$ \\
2LARGE & $(-)$ & $\mathbf{- 0 . 0 6 6}$ & $\mathbf{- 2 . 1 1 3} * *$ \\
ALL(t-1) & $(+)$ & $\mathbf{0 . 1 5 8}$ & $\mathbf{4 . 3 5 9} * * *$ \\
NPL & $(+)$ & $\mathbf{0 . 4 7 9}$ & $\mathbf{1 2 . 7 0 2} * * *$ \\
$\triangle$ NPL(t+1) & $(-)$ & $\mathbf{- 0 . 0 5 0}$ & $\mathbf{- 1 . 4 5 3}$ \\
LOAN & $(-)$ & $\mathbf{- 0 . 0 4 5}$ & $\mathbf{- 1 . 1 7 9}$ \\
SIZE & $(+)$ & $\mathbf{0 . 0 8 5}$ & $\mathbf{2 . 1 1 3} * *$ \\
NI & $(+)$ & $\mathbf{0 . 0 3 6}$ & $\mathbf{1 . 0 2 2}$ \\
BIS & $(-)$ & $\mathbf{0 . 1 4 8}$ & $\mathbf{3 . 9 0 9} * * *$ \\
SEOUL & $(-)$ & $\mathbf{- 0 . 1 3 9}$ & $\mathbf{- 3 . 4 9 3 * * *}$ \\
YD & & & Included \\
\hline & & & Adj: 0.337 \\
\hline
\end{tabular}

Table 4 shows the main results for the regression model. Mutual Saving Banks with higher equity from the second largest shareholder shows a lower Discretionary portion or Alloance for Loan Losses (DALLs). The coefficient of $2 L A R G E$ is -0.066 and is significant at the 5\% level, providing support for the hypothesis that a firm with high second largest shareholder equity is less likely to have earnings management by managers for their own interest.

The coefficient of $A L L_{t-1}$ is 0.158 and is significant at the $1 \%$ level, indicates that the larger the initial allowance, the larger the Discretionary portion of Allowance for Loan Losses (DLLPs). The coefficient of NPL is 0.479 and is significant at the $1 \%$ level. This means the banks with large Non-Performing Loans (NPL) have the larger Discretionary portion of Allowance for Loan Losses (DLLPs). The coefficient of SIZE is 0.085 and is significant at the $5 \%$ level, means the bigger the banks' asset is, the possibility of the earnings management increased. The coefficient the BIS is 0.148 and significant at the $1 \%$ level. Actually, we expected the coefficient of BIS negative, but the result came out positive.

The coefficient of SEOUL is -0.139 and is significant at the $1 \%$ level, means the Mutual Saving Bank whose headquarters are located in Seoul and/or the capital area, are subject to strict oversights by regulation authority, so they are less likely to have earnings management. Lastly, the coefficient of Changes in Non-Performing Loans ( $\Delta \mathrm{NPL}$ ), LOAN and NI is not significant.

\section{Conclusions}

This study examines whether the second largest shareholder's holdings are related to the earnings management by Mutual Savings Banks. The motivation behind this paper is the Mutual Savings Banks crisis and restructuring during 2011 2014.

In general, the financial institutions in Korea has controlled by strict ownership restrictions and it is not possible to hold more than $10 \%$ (nation-wide banks) or 15\% (locan-banks). However, this ownership limitation is not applied for the Mutual Savings Banks, so the largest shareholder of the Mutual Savings Banks can hold even 100\% of their banks.

There are many facts which caused the Mutual Savings Banks crisis, but one of the most important cause is the weak governance system, which enabled the largest shareholder to manage their earnings for their private interest.

In this regard, we tried to find the relationship between the ownership structure of the Mutual Savings Banks and Earning Management. We predicted that the Mutual Savings 
Banks with more diversified ownership structure, the earnings management can be reduced. In other words, effective second largest shareholders can control the earnings management by management and/or the largest shareholders for their private interest, so the earnings management may be less likely, among the savings banks with large shares.

We investigated the relationship between the second largest shareholders and earnings management by Discretionary portion of Allowance for Loan Loss (DALLs), the account which is used to measure the earnings management of financial institutions. Using a sample of 688 Mutual Savings Banks in Korea from 2003 to 2012, we examine whether the magnitude of Discretionary portion of Allowance for Loan Losses (DALLs) is related to the second largest shareholder's holdings.

We verified this assumption by considering savings banks with the second largest shareholder that managed their earnings through the discretionary share of the allowance account showing less opportunistic earnings management. The results showed that those savings banks with the second largest shareholder have significant negative (-) effects on their discretionary shares of the allowance account. This suggests that the stronger the second largest shareholder's control over the firm is, the less likely the opportunistic earnings management will be.

The result of this study contributes to defining information value of the second largest shareholder's equity holdings for the Mutual Savings Bank's earnings managements. Additionally, this study extends the literature on the relation between equity ownership structures and earnings management by showing that the effect of the second largest shareholders equity holdings on earnings management.

Recent studies have emphasized whether financial institutions using their allowance for loan losses for earnings management. This paper extends the literature on savings bank's earnings management by verifying that the second largest shareholder has significant negative relations with earnings management. Also, this study deal with financial institution's governance structure in terms of accounting approach.

\section{References}

[1] W. Paek and H. Cho, "Ownership Holding by Second Largest Stockholder and Earnings Management, Asia-Pacific Journal of Financial Studies", vol. 35, (2006), pp. 103-139.

[2] A. Shleifer and R. Vishny, "A Survey of Corporate Governance, Journal of Finance”, vol. 52, (1997), pp 737-783.

[3] R. La Porta, F. Lopez-De-Silanes, A. Shleifer, and R.Vishny, "Law and Finance, Journal of Political Economy", vol. 106, (1998), pp. 1113-1155.

[4] R. La Porta, F. Lopez-De-Silanes, A. Shleifer and R.Vishny, "Investor Protection and Corporate Governance", Journal of Financial Economics, vol.58, (2000), pp. 3-27.

[5] J. Park, "Corporate governance and earnings management," View from the largest shareholders's holding, Korean accounting review, vol. 28, no. 2, (2003), pp. 135-172.

[6] P. Park, J. Jang and G. Jeung, "An Empirical Study on the Relationship between Corporate Governance and Earnings Management”, Korean Accounting Information Review, vol. 24, no. 1, (2006), pp. 213 241.

[7] H. Ahn, and R. Seo, "The Corporate Governance and Earnings Management, View from multiple large shareholders and control contest”, Korea Accounting Review, vol. 38, no. 1, (2013), pp. 43-85.

[8] A. Beatty, S. L. Chamberlain and J. Magliolo, "Managing financial reports of commercial banks: The influence of taxes, regulatory capital, and earnings", Journal of Accounting Research 33(Autumn), (1995), pp. 231-261.

[9] M. Hyun-Ju, "Earning Management by Banks through Specific Accruals Approach", Korea Accounting Review, vol. 29, no. 2, (2004), pp. 111-131.

[10] M. M.Cornett, J. J. McNutt and H. Tehranian, "Corporate governance and earnings management at large U.S. bank holding companies”, Journal of Corporate Finance vol. 15, (2009), pp. 412-430.

[11] W. H Beaver and E. E. Engel, "Discretionary Behavior with respect to Allowances for Loan Losses and the Behavior of Security prices", Journal of Accounting and Economics, vol. 22, (1996), pp. 177-206. 
International Journal of $u-$ and $\mathrm{e}-$ Service, Science and Technology

Vol.9, No. 3 (2016)

\section{Authors}

Hyun-Jung Kang, First Author: Ph.D. Candidate, Graduate School of Gyeongsans National University, 501, Jinju-Daero, Jinju 660-701. South Korea (Email: hjkang8@gnu.ac.kr).

Soon-Mi Yu, Corresponding author: Assistant Professor, BERI, Department of Accounting, Gyeongsans National University, 501, Jinju-Daero, Jinju 660-701. South Korea (Email: smyu@gnu.ac.kr). 